\title{
Improving the mechanism as a means of sustainable industries of Uzbekistan
}

\author{
Safarov B.Sh., \\ Doctor of Economics, Professor, \\ Head of department Samarkand State University, \\ Samarkand, Republic of Uzbekistan, \\ safarovb@rambler.ru
}

\begin{abstract}
The article examines and highlights the problems, related to the poor use of the capacity of the regions of Uzbekistan . To improve the current situation during a pandemic, some sectors of the economy, taking into account world experience, need strengthening and marketing. Today different mechanisms for production of interaction have been proposedat the regional level. This approach is capable of radically changing the structure of the regional economy.

Key words: pandemic, marketing, mechanism, management, innovation, market, goods.
\end{abstract}

\section{Introduction}

The coronavirus pandemic and quarantine measures to contain it have had a sharp and widespread shock to the global economy, with the production slump going to be the deepest since World War II. According to the forecasts of the World Bank, this year the planet's economy will contract by an average of 5.2 percent. This data is from the June issue of the World Bank's World Economic Outlook report. Advanced economies are expected to contract 7 percent, while emerging and developing economies will slow down by an average of 2.5 percent. Per capita incomes could fall 3.6 percent this year, putting millions of people in poverty. The hardest hit will be for countries most affected by the pandemic, as well as those whose economies depend on international trade, tourism, raw materials exports and external financing.

Production in the euro area is expected to decline by 9.1 percent in 2020, as the widespread spread of coronavirus in major countries has hit hard business activity. The United States may lose 6.1 percent of GDP this year the country was among the hardest hit by the coronavirus, and measures to combat the pandemic cost the budget dearly. The Japanese economy is also forecast to lose 6.1 percent of GDP - preventive measures have caused a slowdown in economic activity there.

When summing up the results of the year, only two states of the region will not be negative. In Turkmenistan, the World Bank believes, growth will be zero this year and positive - at a rate of 4 percent - next. But the economy of Uzbekistan already by the results of 2020 will be, albeit in a small, but positive - 1.5 percent, and in 2021 it will be able to demonstrate 6.6 percent of economic growth.

Literature review.

There are scientific works of foreign, local economists, scientists on theoretical and methodological foundations of financial accountability, as well as the problems of using international standards in studying the order of financial accounting and reporting including: J.Pazarbashioglu, Ayhan Kose, I.Tuxliev, B. Safarov and others.

\section{Main part.}

In the Message of the President of Uzbekistan to the Parliament of the country for 2020, which was declared the "Year of Development of Science, Education and the Digital Economy", it was indicated that an accelerated transition to the digital economy will be a priority for the next five years.

This implies a constant increase in investment in tourism, which is happening despite the difficulties associated with the pandemic. According to the Ministry of investment and trade, in the first half 2020 , the investment in information and communication technology (ICT) increased 3.5 times compared to the same period in the previous year.

In the first half of 2020, total investment in fixed assets declined slightly, while foreign direct investment (FDI) and loans, on the contrary, increased. Despite the decrease in the total volume of investments, investments were directed to the ICT and communications sector by about 1.8 times, and FDI and loans - 1.3 times more, compared to the same period last year. The share of investments in ICT and communications in the total volume of investments also increased from $1.3 \%$ to $2.3 \%$, and in the volume of FDI and loans - from $1.9 \%$ to $2.2 \%$.

For 2020, in accordance to the Investment Program, the total volume of investments is projected at 129.1 trillion soums, of which investments in the ICT industry are projected at 1.8 trillion. sum, or only $1.4 \%$ of the total 
investment. The share of investments in the ICT sector of the total projected investment volumes for 2021 and 2022 is also $1.5 \%$ and $1.4 \%$, respectively.

Thus, despite the growth in the projected absolute values of investment in the ICT sector, its share in the total investment volume does not increase and remains practically unchanged.

The coronavirus pandemics has forced many processes in commerce, education, management, office work and other areas to go online, which, in turn, has increased the demand for ICT and communications services. Experts predict that in many countries, the coronavirus pandemic will accelerate the digitalization of their economies. At the same time, the most dynamic investment growth is predicted in such areas as the creation of new software products, "cloud" technologies, robotization, and the creation of artificial intelligence.

In the structure of the world market of ICT services, the main shares are occupied by software $-75 \%$ and telecommunications services - $15 \%$. The development of these segments requires a constant increase in the coverage and throughput of existing telecommunication networks. At the same time, the expansion of the telecommunications network by laying a fiber-optic cable makes it possible to provide subscribers with several services at once through one communication line - telephone communication, Internet access and digital television.

Increased investment in information and telecommunications, not only aims to increase exports and IT services, but also stimulates the development of innovations, contributes to the emergence of new economic activities, increase productivity and quality of life.

Implementation of projects in Uzbekistan in the sphere of ICT, in accordance with the Investment Program for 2020-2022, which made the appropriate adjustments to the pandemic, will significantly improve the existing infrastructure for the development of the digital economy and growth provided in the service sector, for which demand during and after the pandemic will only increase.

The pandemic is negatively affecting the implementation of major investment projects in many countries of the world. In Uzbekistan, their implementation is also experiencing certain difficulties associated, in particular, with the arrival of foreign specialists in the country due to coronavirus restrictions. Measures are being taken to continue the implementation of projects important for the country. The article also provides information on what investment projects are being implemented in the chemical industry of Uzbekistan.

Thanks to timely measures to create all the necessary conditions for the smooth operation of the industry during the coronavirus pandemic, in the first half of 2020, sustainable development of chemical enterprises was achieved. For the first half of 2020, the enterprises of "Uzkimyosanoat JSC" produced marketable products in the amount of 3669.8 billion soums, whose growth rate of production compared to the same period in 2019 amounted to 100.0\%. The volume of consumer goods production amounted to 34.8 billion soums. Works continued on expanding the range of products on the basis of deep processing of local raw materials, production of import substituting and export oriented finished products and ensuring production efficiency.

At a videoconferencing meeting held on July 16 this year, which was dedicated to new projects in the field of industry, President Sh.M. Mirziyoyev pointed out the need to consistently continue work on establishing the production of synthetic fibers, polyester resins, polymers, aromatic hydrocarbons, which are in demand in the construction, automotive and pharmaceutical industries. At present JSC " Uzkimyosanoat " is working on 52 investment projects. The total project cost of the facilities is about $\$ 9.7$ billion . Of these, 21 projects are in the active phase of implementation, 18 projects are designated as promising for the coming years, 8 projects are at the study stage, and 6 projects have been proposed for implementation by private entrepreneurs. As a result of the implementation of the projects, it is planned to produce more than 150 types of products for a total amount of $\$ 4.3$ billion a year and create almost 6 thousand jobs. The work is carried out in the areas of production of inorganic chemistry products (15 projects), organic chemistry (23 projects), polymers (12 projects) and $\mathrm{R} \& \mathrm{D}$ (2 projects). The implementation of the projects is expected to increase the volume of exports by $\$ 1.5$ billion and reduce its imports by $\$ 1.1$ billion.

Summing up, we can say that the measures taken made it possible to avoid a sharp decline in production in the chemical industry. Despite the quarantine restrictions, the implementation of important investment proe a comrade in continuing the industry about ops launch new investment projects with foreign partners.

COVID-19 continues to have a negative impact on the global economy. The global textile and clothing market does not stand aside and is experiencing serious difficulties in connection with the disruption of the established supply chains, a sharp reduction in orders, and quarantine measures.

Between May 20 and June 8, 2020, ITMF conducted its fourth survey of textile businesses around the world on the impact of the COVID-19 situation on their operations. The respondents noted a $42 \%$ decrease in current orders. Expectations for a decrease in trade turnover at the end of the year have generally not changed in comparison with the previous survey. The turnover is expected to decrease by $32 \%$ compared to 2019 . At the same time, the greatest decline is expected in the East and South Asia.

The Uzbek textile industry continues to show positive dynamics in the first half of the year, despite COVID-19, and remains attractive for investment. 
Meanwhile, the industry was able not only to maintain positive dynamics, but also to surpass last year's indicators. According to the State Statistics Committee, the production of textiles increased by $13.1 \%$ in the first half, while in 2019 over the same period it was only $2.1 \%$. At the same time, apparel production fell by $0.7 \%$. Separately, it is necessary to dwell on the production of products that have become acutely in demand during a pandemic. The industry was faced with the task of increasing the production of protective masks to 5 million pieces in a short time . in a day. In the second quarter, the domestic textile industry reached a daily output of more than 6 million pieces of masks, 115 thousand protective overalls. At the same time, the existing capacities make it possible to additionally increase the production of these products. Domestic enterprises in a short time were able to convert to the production of previously unproduced products. In the period from March to June, the number of enterprises producing protective masks increased 15 times. The production of personal protective equipment (masks, overalls, gauze) and raw materials for their production spun bond, melt blown, medical gauze and knitted fabrics) has been manufactured.

For the successful current development of the industry, the achievement of forecast indicators, timely implementation of investment projects, attraction of investments, both external and internal, and the creation of new industries remain extremely important. In a pandemic, the implementation of investment projects is influenced by delays or cancellation of the supply of necessary materials and equipment. In the context of severe restrictions on interstate transport communication, the arrival of specialists from abroad also faces difficulties. Meanwhile, as the statistical data for the half-year show, in general, investment activity in the textile and garment and knitwear industries continues to develop dynamically. According to the Ministry of Investment and Foreign Trade, the inflow of investments in the textile industry in the first half of the year increased 1.6 times compared to the same period last year.

Thus, the results of the first half of the year for the Uzbek textile industry as a whole remained positive. It was possible to avoid a large-scale long shutdown of enterprises and mass layoffs of workers, as was observed in many countries - large manufacturers and exporters of textiles and clothing. The positive dynamics of production and exports speaks of the stability of the domestic industry to large-scale crisis phenomena and the accumulated safety margin. According associative «Uztekstilprom» exports reached 1 billion. USD, Which is $12 \%$ more than the same period last year. Despite this, the situation in the countries that are the main importers of Uzbek textile products continues to cause concern. Therefore, the measures taken to quickly remove restrictions on foreign markets for Uzbek textiles and expand sales markets for domestic products are quite relevant .

The negative impact of the coronavirus pandemic also affected the work of enterprises in the electrical industry. During the quarantine measures, some enterprises temporarily suspended their work, difficulties arose with the implementation of investment projects, in particular, due to the impossibility of the arrival of foreign specialists. Quarantine measures limited the operation of retail outlets and the sale of manufactured products, in particular, household appliances.

In this regard, within the framework of the activities of the Republican Anti-Crisis Commission, the necessary conditions were created for the enterprises of the industry to continue production activities in a regular mode and implement most of the planned investment projects. In addition, home appliance manufacturers have launched an online shopping platform since March 15 for the convenience of consumers.

Thus, despite the difficulties encountered, the enterprises of the industry, based on the results of work for the first half of 2020, managed to achieve the planned production indicators and continue the implementation of most of the projects that were included in the Investment Program for 2020-2022. The volume of production in the first half of 2020 amounted to 5126.7 billion soums, or $121.5 \%$ of the forecast for the half-year, the growth rate versus the corresponding period of $2019-121.9 \%$. Exported products for 113.8 million dollars, 1.3 times more than in the same period last year. The industry's share in industrial production was 3.1\%, and its share in total exports was $1.8 \%$. In the first half of the year, 64.3 million dollars of investments were disbursed, which is 1.2 times more than the planned forecast indicators (52.2 million dollars were planned), of which direct foreign investments and loans amounted to 44.9 million dollars ., which is 5 times more than planned (9.0 million dollars were planned). When comparing direct foreign investments in the industry in the first half of 2020 with the indicators of the same period in 2019 (\$3.45 million), it can be seen that they grew 13 times. The volume of production by the end of 2020 is planned to be increased to 9419.7 billion soums, which corresponds to the fulfillment of the annual forecast indicators by $100 \%$ (the growth rate will be $122.3 \%$ ). In total, by the end of the year it is planned to process 49.0 thousand tons of copper raw materials into finished products with added value. In 2020, it is planned to implement a total of 11 investment projects worth 135.4 million dollars with a commissioning date in the fourth quarter. This will create 1,844 new jobs. The volume of investments projected for 2020 is $\$ 191.5$ million, which is 2.7 times more than in 2019 (\$ 69.9 million), of which $\$ 44.9$ million will be direct foreign investments and loans (1.4 times more than planned). In 2019, the export of electrical products amounted to $\$ 250$ million, in 2020, exports may reach \$ 300 million.

Currently, the interested ministries and departments are finalizing the draft Concept for the development of the electrical industry for 2020-2030, which may also reflect the above tasks. Fulfillment of the set goals and objectives, as well as the adoption and implementation of the Concept for the development of the electrical industry will allow it to become one of the leading industries in the republic. 


\section{CONCLUSION}

The faster states move to the digital economy, the more actively industry will begin to develop, its productivity will increase, social welfare will increase, and consumers will receive more benefits by saving time and money. "Building a successful digital economy requires the broadest material and technical base and huge production capabilities, but countries' resources are often depleted and their funds are limited. Our plans are ambitious, but feasible. The state has already laid a solid foundation for development, we just have to work.

\section{REFERENCES}

\# Efremova MV, Development of the Russian tourism industry in the context of the crisis. Magazine "Marketing in Russia and Abroad" - 2010., - №2. - p. 115-120.

* Baumgarten LV, Study of consumers of tourist services. Magazine "Marketing in Russia and Abroad" - 2007., № 2. - p.34-45.

* Safarov B. Sh. The models of prognosis of regional tourism's development // International Cross-Industry Research Journal (Perspectives of Innovations, Economics and Business). -Republic of Czech, 2010. - No. 6.P.80-83.

\# Bulletin of the State Committee on Statistics "Main indicators of the economy of Uzbekistan. " T : Goskostat , $2020.121 \mathrm{p}$.

* 5, https://www.vsemirnyjbank.org/ru/news/press-release/ 